\title{
Prevalence and degrees of myopia and hyperopia at Gondar University Hospital Tertiary Eye Care and Training Center, Northwest Ethiopia [Corrigendum]
}

\author{
Shiferaw Alemu D, Desalegn Gudeta A, Tsega Ferede A, \\ Woretaw Alemu H. Clin Optom (Auckl). 2016;8:85-91.
}

On page 85, the correct article title should read as follows: Prevalence and degrees of myopia and hyperopia at University of Gondar Hospital Tertiary Eye Care and Training Center, Northwest Ethiopia. The correct affiliation name should read as follows:

Department of Optometry, College of Medicine and Health Sciences, University of Gondar, Gondar, Ethiopia. The correct correspondence details should read as follows:

Correspondence: Destaye Shiferaw Alemu

Department of Optometry, College of Medicine and
Health Sciences, University of Gondar, PO Box 196, Gondar, Ethiopa

Tel +2519180322

Email destayest@gmail.com

During manuscript submission, the authors mentioned affiliation name as Gondar University instead of using the correct and officially recognized name "University of Gondar." The University Academic Board from the University of Gondar had requested all authors only use the proper affiliation name "University of Gondar". The authors apologize for this oversight.

\section{Publish your work in this journal}

Clinical Optometry is an international, peer-reviewed, open access journal publishing original research, basic science, clinical and epidemiological studies, reviews and evaluations on clinical optometry. All aspects of patient care are addressed within the journal as well as the practice of optometry including economic and business analyses. Basic and clinical research papers are published that cover all aspects of optics, refraction and its application to the theory and practice of optometry. The manuscript management system is completely online and includes a very quick and fair peer-review system, which is all easy to use. Visit http://www.dovepress.com/ testimonials.php to read real quotes from published authors. 